\title{
Rice field cultivation on tin-mined land in Bangka Island, Indonesia
}

\author{
E. Nurtjahya Universitas Bangka Belitung, Indonesia \\ M.M. Nur Bangka Goes Green, Indonesia \\ E. Mulyono Bangka Goes Green, Indonesia
}

\begin{abstract}
Changing from previously tin-mined land into rice fields is good practice for increasing food stability in the province of Bangka Belitung Islands, as most major staples currently come from other islands. This pioneering project of Bangka Goes Green is a corporate social responsibility of a private tin smelter consortium in Pangkalpinang. Rice fields with an average area of $750 \mathrm{~m}^{2}$ were planted for the first time in October 2008. Rice field cultivation on previously tin-mined land has not been practiced before in this province. About of $16 \mathrm{~m}^{3}$ mineral soil and 26 t of compost were added to each newly constructed plot. Each hectare of 105-110 day rice field produced about 4-5 t dried unhulled rice, yielding 2.4-3 trice grain, $25 t$ straw, 1.2-1.5 thusk, and 0.4-0.5 kg bran. The yields of IR64 dried unhulled rice and rice grain was close to those from unmined soil, i.e. $4-5 t$ and 3 tha consecutively. From the heavy metal content perspective, the rice grain is considered safe with no significant difference in contents for mined and unmined husks. If construction costs, mineral soil supply and compost costs are excluded, the pilot project benefits are about 9-12.8 million Rp/ha, if these costs are inclusive it suffers losses of 10-13.7 million Rp/ha. The economic benefit of rice field cultivation cannot, therefore, compensate the environmental recovery of previously mined land. Apart from this agricultural success, considerable efforts now have to be made to modify the soil amendment procedures in order to increase the benefits which may cover environmental loss.
\end{abstract}

\section{Introduction}

Tin mining in Bangka Island has been exploited for about a hundred years and gained in intensity during the Dutch colonial period. Bangka is the largest tin producing island in Indonesia, contributing $40 \%$ of world demand of tin (ASTIRA, 2005). Bangka is the largest tin producing island in Indonesia (Figure 1). Tin mining leaves disturbed land, ex-tin mining ponds, damages natural drainage and habitats, and causes pollution. Sand tin tailings may have $95 \%$ sand, C-organics less than $2 \%$, cation exchange capacity less than 1.0 , and its soil temperature may reach $45^{\circ} \mathrm{C}$ (Nurtjahya et al., 2008a).

It has been become a significant topical issue in Indonesia on how to utilise previously tin-mined lands in the province of Bangka Belitung Islands (Figure 2), as tin is a finite supply. Tin-mined lands are considered useless lands and take a long time to recover. Together with other marginal lands, the total of mine-impacted lands in the province totals 1,642 ha (Metro Bangka Belitung, 2008), or even more than 5,000 ha if those which have been already reclaimed and revegetated are included (Nurtjahya, 2008). Newly left created previously tin-mined land is about $80 \mathrm{~cm}$ difference in the two soil surfaces. The global crisis which affects tin industries in the province has made people pay more attention to agricultural production. Agriculture has been neglected in the last ten years since the reformation era started, and was followed by a series of autonomy and mining regulations which have given the local government more authority to manage its resources. Land use has changed from pepper and rubber plantation to mining (Nurtjahya et al., 2007a), and in the coastal area a change of profession from fishermen to miners has been reported (Nurtjahya et al., 2008b). 

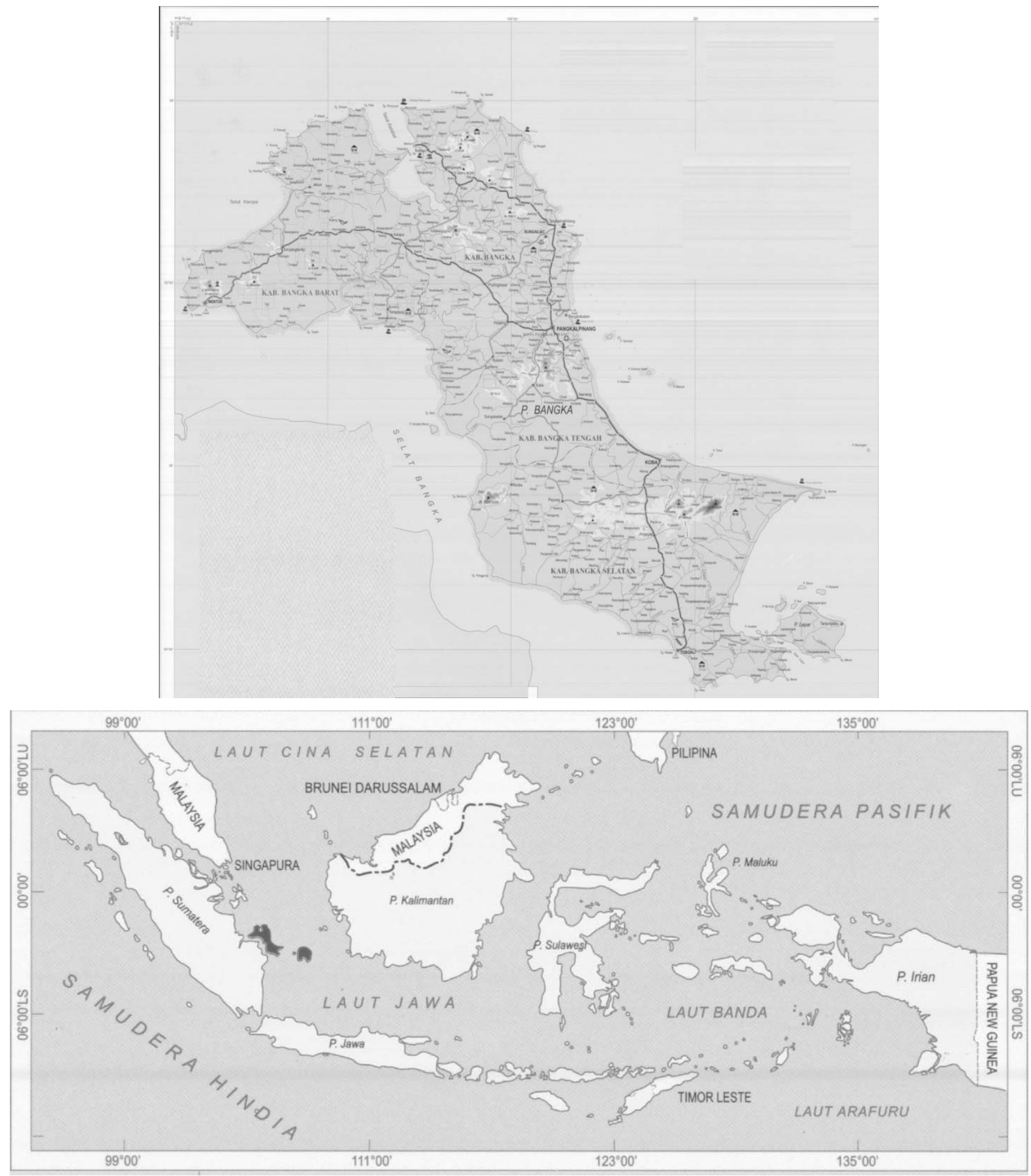

\section{Figure 1 Bangka Island}




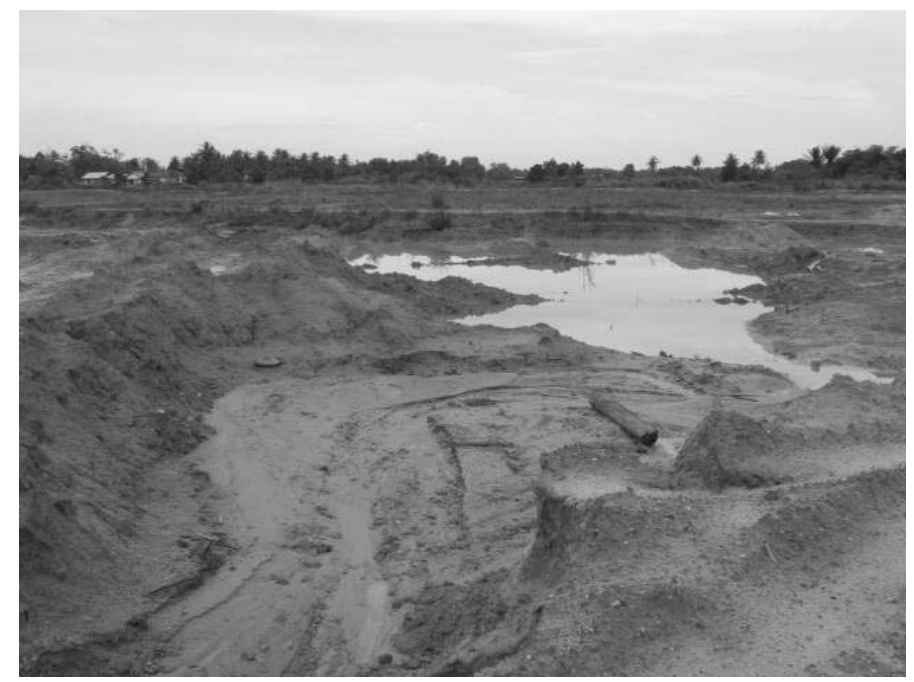

Figure 2 Previously tin-mined land in a rice field area

Studies show that some efforts to restore previously tin-mined lands face significant challenges. Reliance on natural succession to restore sand tin tailings without any human intervention will take a long time before an effective cover is established (Mitchell, 1959; Ang, 1994; Nurtjahya et al., 2007b). Studies of natural regeneration showed that the dominant species, up to 11 years after mining, belong to the families Cyperaceae and Poaceae, while shrub species are common after 40 years (Nurtjahya et al., 2007b). The slow process of natural colonisation results from the degraded physical and chemical soil properties. The texture of mined land is usually sandy and is low in organic matter content, cation-exchange capacity (CEC) and hence exchangeable cations (Nurtjahya et al., 2007b). Research on soil amendments has been performed by using various sources of organic and inorganic materials (Siagian and Harahap, 1981; Puryanto, 1983; Sastrodihardjo, 1990; Naning et al., 1999; Nurtjahya, 2001), including the application of arbuscular mycorrhizal fungi.

Planting vegetables is practiced by a very small group of people in Bangka Island, and is generally successful. The farmers plant annual crop plant species (mustard, eggplant, beans, water melon, melon, maize and chilli) with the help of biosolids usually from their own animal husbandry of livestock (cow, goat, chicken, or pig). Research on planting local tree species to enhance forest restoration was initiated a few years ago. One species, Syzygium grande (Wight) Wight ex Walp. (Myrtaceae), has been reported as a potential candidate for revegetating previously tin-mined land (Nurtjahya et al., 2008c).

Establishing a rice (Oryza sativa L. - Poaceae) field on previously tin-mined land integrated with animal husbandry is a pioneering project not thought possible by the local inhabitants. The common perception is that previously tin-mined lands are very unproductive and take many decades to recover or to be reused. As a result of the initial success of harvesting rice, Bangka Goes Green (BGG) invited a number of local and national officials to visit the rice field area in November 2008, and the activity has now become a benchmark for other mining industries in other parts of Indonesia. BGG is the name of the programme of PT Bangka Belitung Timah Sejahtera's corporate social responsibility of a consortium of nine tin smelter companies in Pangkalpinang, the capital of the province. BGG was established in 2008. The aim of this organisation is to recover the tinned mining lands and to build environmental awareness of local people.

The BGG programme in rice field cultivation on tin-mined areas also inspired other local governments in the province, and some local groups are eager to do the same. Whilst some people raised concerns about the health implications of the long-term consumption aspects of rice cultivated on previously mined land, due to a fear of heavy metal bioaccumulation, others are interested in studying the agronomy in marginal and amended rice fields, in particular, planting density, planting season, inorganic and organic fertilisers, control of pests and diseases, with the aim of producing a guidance manual for common people.

The other economics of the venture has also been questioned. The use of heavy agricultural machinery for rice field construction requires a considerable budget. Soil amendment, i.e. the cost of adding mineral soil and compost, may also be major component of the total cost of land preparation. What quality and quantity 
of ameliorant to amend a certain physical and chemical quality of a tin-mined land? Is it still feasible, especially for local people?

This paper reviews current rice field operations on previously tin-mined land and discusses whether this practice is feasible, attention is also paid to the heavy metals issue. The discussion may encourage agricultural practice integrated with husbandry on previously tin-mined land to be more productive and feasible, and guide provincial government policy on food stability.

\section{Methodology}

\subsection{Study sites}

A 3.5 ha previously-mined rice field is located at Jeruk village, Bangka Island, Indonesia (lat. $02^{\circ} 11^{\prime} 38.2^{\prime \prime}$; long. $106^{\circ} 09^{\prime} 16.6$ 'E; $10 \mathrm{~m}$ above sea level). Mean annual rainfall (1996-2005) is 2,408 mm, and temperature ranges from $23.8-31.5^{\circ} \mathrm{C}$, with an average of $26.8^{\circ} \mathrm{C}$ (Pangkalpinang Meteorology Station, 2006). Twenty-nine of a total of 49 plots with the average of $700 \mathrm{~m}^{2}\left(300-2,300 \mathrm{~m}^{2}\right)$ have been planted 1-4 times. The first planting was on 22 October 2008. A control site for soil was an area of rice fields located at Tanah Bawah village, Bangka Island, about $50 \mathrm{~km}$ from Jeruk village, and a nearby secondary forest. A rice husk control was collected from a rice field at Pangkalan Nyiur village, Bangka Island, about $70 \mathrm{~km}$ from Jeruk village.

\subsection{Soil and plant tissue sampling}

Soil was sampled at 0-20 cm using an $8 \mathrm{~cm}$ diameter auger. Diagonal composite (Setyorini et al., 2003) samples of 9-18 subsamples per plot were taken, and one to two replicates were analysed. Single samples were used for previously tin-mined land, new sandy rice field plus clay, sandy clay rice field, the reference rice field, and the reference forest soil, while two replicates were chosen for sandy rice field and the clay rice field. Straw samples from two harvests of two different plots were analysed for major nutrients N, P, K and the heavy metals $\mathrm{Fe}, \mathrm{Pb}, \mathrm{Cd}, \mathrm{Cu}$ and $\mathrm{Sn}$, with a control from the unmined rice field. Rice grains from three harvests of three different plots and a control from the unmined rice field were analysed for water, ash, protein, lipid, fibre, and energy contents, as well as for $\mathrm{Pb}, \mathrm{Cd}, \mathrm{Cu}$ and $\mathrm{Sn}$ concentrations.

\subsection{Land preparation}

Mined land with 3-15 m holes was levelled by bulldozer. The rice field was constructed by a large excavator with the average five $\mathrm{hr}$ operation time per plot. Approximately $16 \mathrm{~m}^{3}$ black mineral soil brought in from another area was added to each plot. A small excavator was used to level the mineral soil so that the rice field had a depth of about $8 \mathrm{~cm}$ of mineral soil. About $2 \mathrm{t}(26.8 \mathrm{t} / \mathrm{ha})$ of sawed dust-cow dung compost was added to each plot and a small tractor was used to mix the soil amendment and plough to the soil. The compost produced by Bangka Goes Green by fermenting dung of about 108 Simmental and 158 Friesian Holstein, and 20 Black Angus cows, sawdust or rice husk, and water plants (1:1:2) with the addition of $25 \mathrm{ml} / \mathrm{t}$ EM-4 microbial solutions and $500 \mathrm{ml} / \mathrm{t}$ molasses. The compost was a good quality one with $\mathrm{pH} 7.3$, water content $42.05 \%$, organic $\mathrm{C} 33.56 \%$, organic $\mathrm{N} 0.74 \%, \mathrm{NH}_{4} 0.12 \%, \mathrm{NO}_{3} 0.03 \%$, N-total $0.89 \%, \mathrm{C} / \mathrm{N}$ ratio 45, $\mathrm{P}_{2} \mathrm{O}_{5}$ 0.87\%, $\mathrm{K}_{2} \mathrm{O}$ 0.47\%, Fe 1,540, Mn 135, Cu 6, Zn 712, B 9 , Pb 3, Cd 0.3, Co 1, As 4, Mo undetected and $\mathrm{Hg} 0.21 \mathrm{mg} / \mathrm{kg}$.

Soil amendment is needed as soil physical and chemical properties of tin-mined lands are poorer than undisturbed land and abandoned farmland (Nurtjahya et al., 2007b). Soil amendment reduces the proportion of the sand fraction while increasing the silt and clay fractions. The organic matter addition to rice field increases organic $\mathrm{C}$ and $\mathrm{N}$ concentrations, $\mathrm{P}_{2} \mathrm{O}_{5}, \mathrm{~K}_{2} \mathrm{O}$ and total exchangeable cations $(\mathrm{Ca}, \mathrm{Mg}, \mathrm{K}, \mathrm{Na})$, and cation exchange capacity (CEC) (Table 1). Some heavy metals, however, show differences between previously mined land, newly clay-added rice fields, rice fields, and the reference rice field and reference forest soils. The higher totals of $\mathrm{Cu}, \mathrm{Pb}$, and $\mathrm{Cd}$ in the reference rice field might be due to the residue of fertiliser application from previous plantings. Sn concentrations do not show a significant increase; the $\mathrm{Sn}$ concentration in previously mined land is similar to that of the reference rice field and reference forest soils. The ploughed plot was left for two weeks before planting. 


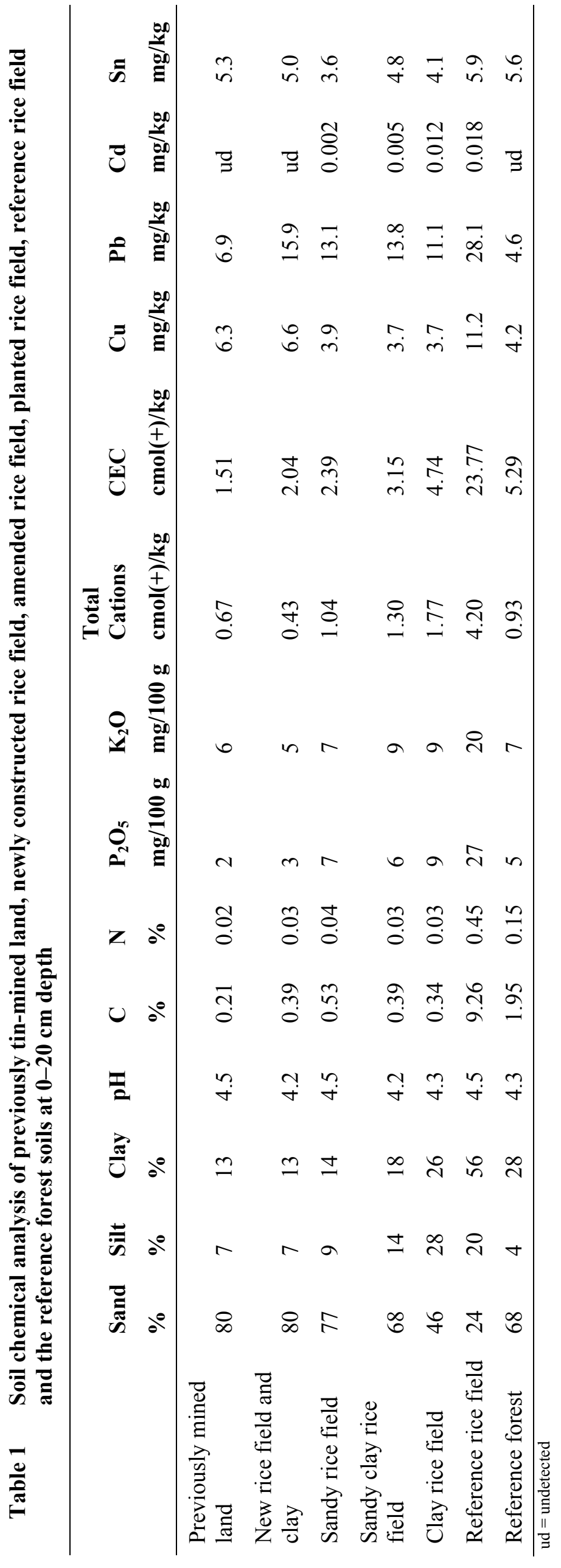




\subsection{Planting and crop management}

Seeds of IR64 rice were germinated in a nursery and then seedlings were planted into the plots, spaced at a distance of $30 \mathrm{~cm}$ (Figure 3). The plants were watered through $12.5 \mathrm{~cm}$ PVC pipes using water extracted from a previous mining pond ('kolong') mixed with cow urine collected from the barn, and from nearby a closed previous mined pond. The water quality analysis of four previous mining ponds showed undetected $\mathrm{Pb}, \mathrm{Cd}$ and $\mathrm{Sn}$ concentrations and about $0.010-0.085 \mathrm{mg} / \mathrm{L} \mathrm{Cu}$. Fertiliser applications were made (average use of fertiliser per plot per season of about 105-110 days was $7 \mathrm{~kg}$ urea and $3 \mathrm{~kg} \mathrm{KCl}$ ). Four to five insecticide applications were made to each plot over the growing season.

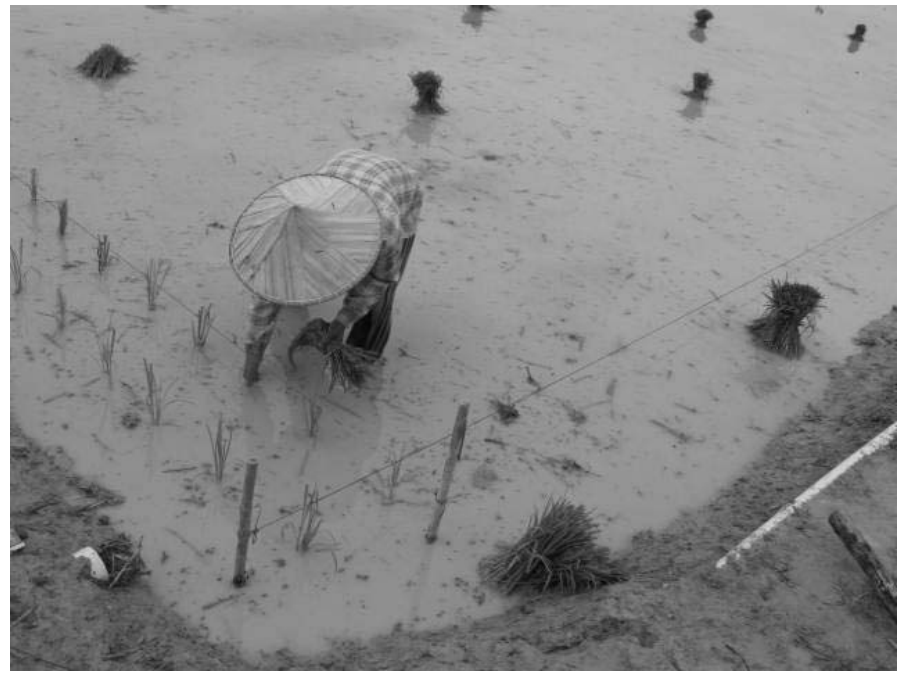

\section{Figure 3 Planting rice seedlings}

\section{Results}

\subsection{Rice yields}

After 105-110 days, rice grain was manually harvested (Figure 4). Every rice field produced about 4-5 t/ha dried unhulled rice, about $2-3 \mathrm{t} /$ ha rice grain, about $2.5 \mathrm{t} / \mathrm{ha}$ straw, about $1.2-1.5 \mathrm{t} / \mathrm{ha}$ husk, and about $0.4-0.5 \mathrm{~kg} / \mathrm{ha}$ bran (Table 2). Using the same rice variety IR64, the average production is 5.5-6.5 $\mathrm{t} / \mathrm{ha}$, or 8-9 t/ha of new variety in unmined field in Java (Kompas, 2009a). Dried unhulled rice price was based on national standard 2,000 rupiahs $(\mathrm{Rp}) / \mathrm{kg}$, rice grain price was based on local market, and the straw, husk, and bran's price were estimated.

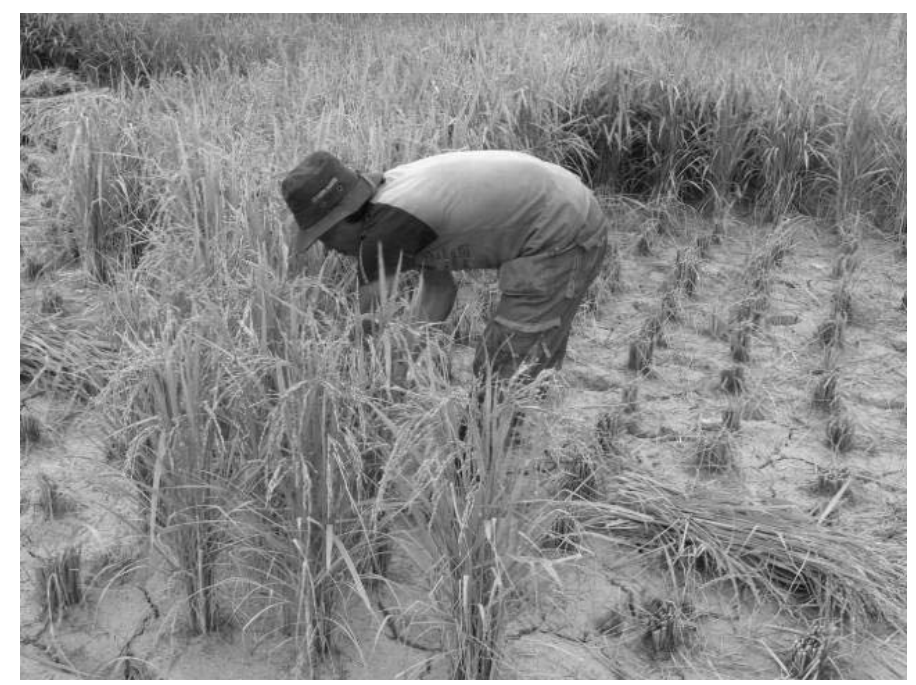

Figure 4 Harvesting rice from the clay sandy soil 
Table 2 Rice yields

\begin{tabular}{llll}
\hline Yields & Unit & Quantity & Value (million Rp) \\
\hline Dried unhulled rice & $\mathrm{t}$ & $4-5$ & $80-100$ \\
Rice grain & $\mathrm{t}$ & $2.4-3.0$ & $14.4-18$ \\
Straw & $\mathrm{t}$ & 25 & 2.5 \\
Husk & $\mathrm{t}$ & $1.2-1.5$ & $0.24-0.3$ \\
Bran & $\mathrm{kg}$ & $0.4-0.5$ & $0.4-0.5$ \\
\hline
\end{tabular}

The main pest of the rice crop is Lonchura striata (Estrildidae) [Indonesian: emprit kaji] birds which eat young to mature rice grains. Its flock may be up to 150 birds which attacked at daytime. Recently, two bird species (Sitta frontalis (Sittidae) [gelatik] and Palceus manyar [manyar kuning] have become regular visitors but only in small numbers. To minimise bird disturbance, some plots are covered with fish net along the top and the edges. Insects, especially hemipteran bugs (Leptocorisa oratorius (Coreidae) [walang sangit] and [kepik] may be controlled by using appropriate insecticides. In other parts of Indonesia, L. oratorius may be responsible for 15-20\% harvest loss (Asikin and Thamrin, 2009).

\subsection{Heavy metal concentrations}

\subsubsection{Rice grain}

The water content of all rice from previously tin-mined rice land (11.15-12.56\%) was lower than that of the control rice $(13.08 \%)$, while the ash content of the control rice $(0.2 \%)$ was the lowest. Previous tin-mined rice $(10.09-11.36 \%)$ had higher protein content than control rice but is relatively lower in lipids $(0.2-0.3 \%)$ and fibre (0.7-1.7\%) contents (Table 3 ). The energy value, however, was similar among three previously tinmined rice and one control rice, i.e. 350-353 kcal/100g. Heavy metal ( $\mathrm{Pb}, \mathrm{Cu}$ and $\mathrm{Sn})$ concentrations, however, showed variability between previously mined and unmined rice, and among mined land rice. The $\mathrm{Pb}$ concentration of the rice control $(0.08 \mathrm{mg} / \mathrm{kg})$ was in the range of that from mined land $(0.06-0.12 \mathrm{mg} / \mathrm{kg})$. Cu concentration in previously mined land rice was generally higher $(0.13-0.18 \mathrm{mg} / \mathrm{kg})$ than the rice control $(0.15 \mathrm{mg} / \mathrm{kg})$, and $\mathrm{Sn}$ was actually higher in the rice control $(0.82 \mathrm{mg} / \mathrm{kg})$ than grain from three mined areas $(0.34-0.47 \mathrm{mg} / \mathrm{kg})$. Cd was not detected of any samples (Table 3$)$. The concentration values of $\mathrm{Cu}$ in rice grain were below the maximum corresponding level of $10 \mathrm{mg} / \mathrm{kg}$ for cereal grains and other food crops, while $\mathrm{Pb}$ contents in rice samples are also below the maximum permitted levels of $0.2 \mathrm{mg} / \mathrm{kg}$ (Rogan et al., 2009).

Table 3 Rice analysis from previously tin-mined and unmined land control

\begin{tabular}{lllll}
\hline & Rice 1 (A4) & Rice 2 (A13) & Rice 3 (A15) & Rice Control \\
\hline Water (\%) & 11.5 & 11.15 & 12.56 & 13.08 \\
Ash (\%) & 0.69 & 1.00 & 0.28 & 0.22 \\
Protein (\%) & 11.36 & 10.25 & 10.09 & 9.16 \\
Lipid (\%) & 0.35 & 0.33 & 0.20 & 0.57 \\
Fibre (\%) & 1.67 & 0.74 & 1.00 & 1.28 \\
Energy (kcal/100 g) & 353 & 353 & 350 & 350 \\
$\mathrm{~Pb}(\mathrm{mg} / \mathrm{kg})$ & 0.06 & 0.12 & 0.07 & 0.08 \\
$\mathrm{Cd}(\mathrm{mg} / \mathrm{kg})$ & $\mathrm{ud}$ & $\mathrm{ud}$ & $\mathrm{ud}$ & $\mathrm{ud}$ \\
$\mathrm{Cu}(\mathrm{mg} / \mathrm{kg})$ & 0.17 & 0.13 & 0.18 & 0.15 \\
$\mathrm{Sn}(\mathrm{mg} / \mathrm{kg})$ & 0.34 & 0.50 & 0.47 & 0.82 \\
\hline
\end{tabular}




\subsubsection{Husk}

In general, the $\mathrm{N}, \mathrm{P}$ and $\mathrm{K}$ concentrations of all previously tin-mined rice grains were lower than the control rice. Copper $(0.6$ and $1.2 \mathrm{mg} / \mathrm{kg})$ and $\mathrm{Pb}(0.7$ and $0.9 \mathrm{mg} / \mathrm{kg})$ concentrations of mined land husks were lower than $\mathrm{Cu}(13 \mathrm{mg} / \mathrm{kg})$ and $\mathrm{Pb}(1 \mathrm{mg} / \mathrm{kg})$ of husk control. Tin (Sn) concentrations in rice husk red-brown leaves were 2.0 and $3.0 \mathrm{mg} / \mathrm{kg}$ respectively and the Cd of husk control $(0.04 \mathrm{mg} / \mathrm{kg})$ was much lower than in the previously-mined land husk $(0.10$ and $0.10 \mathrm{mg} / \mathrm{kg})$. The relatively higher $\mathrm{Fe}(822 \mathrm{mg} / \mathrm{kg})$ and $\mathrm{Cd}$ $(0.10 \mathrm{mg} / \mathrm{kg})$ concentrations in rice husk with red-brown leaves than Fe concentration of rice husk control $(375 \mathrm{mg} / \mathrm{kg})$ and previously mined land rice husk with yellow leaves $(418 \mathrm{mg} / \mathrm{kg})$ and $\mathrm{Cd}$ concentration of rice husk control $(0.04 \mathrm{mg} / \mathrm{kg}$ ) (Table 4$)$ might be the reason the leaves' colour was red-brown from the tip up to nearly half the husk.

Table 4 Husk analysis of previously tin-mined and unmined control

\begin{tabular}{lllllllll}
\hline & $\mathbf{N}$ & $\mathbf{P}$ & $\mathbf{K}$ & $\mathbf{F e}$ & $\mathbf{C u}$ & $\mathbf{P b}$ & $\mathbf{C d}$ & $\mathbf{S n}$ \\
& $\mathbf{\%}$ & $\mathbf{\%}$ & $\mathbf{\%}$ & $\mathbf{m g} / \mathbf{k g}$ & $\mathbf{m g} / \mathbf{k g}$ & $\mathbf{m g} / \mathbf{k g}$ & $\mathbf{m g} / \mathbf{k g}$ & $\mathbf{m g} / \mathbf{k g}$ \\
\hline Rice husk yellow leaves (control) & 1.56 & 0.16 & 0.43 & 375 & 13 & 1 & 0.04 & 3.0 \\
Rice husk yellow leaves & 0.59 & 0.10 & 0.83 & 418 & 0.6 & 0.7 & 0.10 & 0.0 \\
Rice husk red-brown leaves & 1.48 & 0.08 & 0.40 & 822 & 1.2 & 0.9 & 0.10 & 2.0 \\
\hline
\end{tabular}

\subsection{Economic values}

The total expenditure per hectare for operating previously tin-mined land as rice fields covered land preparation, nursery, planting, maintenance and harvest. The main components of land preparation were rice field construction with wages included; $(27.5 \%)$, mineral soil $(2.6 \%)$, compost $(42.8 \%)$, diesel for ploughing $(0.3 \%)$, and wages for ploughing $(0.8 \%)$. The income was generated from the selling of rice grain (82.1-84.5\%), husk (11.7-14.2\%), straw (1.4\%), and bran (2.3-2.4\%). Husk, straw and bran were used to make compost.

The total expenditure to convert 1 ha of previously tin-mined land into rice field was estimated at 31.3 million $\mathrm{Rp}$ where the land preparation component was the major portion (about $62 \%$ ) while wages were less than $30 \%$. Almost $50 \%$ of the costs come from the physical and chemical soil property improvement (Table 5). This high operational cost does not equal the economic benefit of tin mining (people's tin mining or 'tambang inkonvensional').

Income from rice grain, straw, husk, and bran was 17.5-21.3 million Rp per ha, the net income per hectare minus land construction was positive at 10.0-13.75 million Rp. The cost of cultivation is greater than the income when the cost of land preparation is included. The loss per hectare is between 10-13.75 million Rp. 
Table 5 Expenditure per hectare for operating previously tin-mined land as rice fields

\begin{tabular}{lrrr}
\hline & & \multicolumn{2}{c}{ Value } \\
\cline { 3 - 4 } Activities & Qty & (million Rp) & $\mathbf{( \% )}$ \\
\hline Land preparation & 1 & 8.6 & 27.5 \\
$\quad$ Rice field construction (wages included) & 16 & 0.8 & 2.6 \\
$\quad$ Mineral soil ( ${ }^{3}$ ) & 13.4 & 42.8 \\
Compost (t) & 26.8 & 0.1 & 0.3 \\
Ploughing (diesel) & 0.3 & 0.8 \\
Wages & 0.0 & \\
Nursery & 0.2 & 0.6 \\
$\quad$ Construction & 0.2 & 0.7 \\
Seeds & 0.5 & 1.5 \\
Wages & 0.0 & \\
Planting & 1.6 & 5.1 \\
$\quad$ Wages & 0.0 & \\
Maintenance & 1.7 & 5.4 \\
Fertiliser (urea, KCl, TSP) & 1.4 & 4.4 \\
Pesticides & 1.2 & 3.8 \\
Wage (weeding, fertilising, pests controlling) & 0.0 & \\
Harvest & 1.4 & 4.3 \\
Wages & 3.5 & \\
\hline Sub-total minus land construction & $\mathbf{1 0 0 . 0}$ \\
\hline Total & &
\end{tabular}

\section{Discussion}

\subsection{Adaptability}

Only species with high heat and drought tolerance or avoidance capacities can survive in stressed conditions of growth in sand tailings (Ang and Ang, 2000). Compared to other life forms, herbs (especially grasses) seem more adaptive on tin-mined lands. It may due to lowest leaf cell suction pressure $(5.4 \mathrm{~atm})$, while shrubs are slightly higher $(6.1 \mathrm{~atm})$, lianas $12.4 \mathrm{~atm}$, small trees $13 \mathrm{~atm}$, and big trees the highest (15.1 atm) (Blum, 1933, in Soerianegara and Indrawan, 2002). As species members of the Cyperaceae and Poaceae dominate the natural succession for up to 11 years on old tin-mined land (Nurtjahya et al., 2007b), these species may have a higher adaptability than other life forms. A few exotic tree species such as Acacia mangium Willd (Fabaceae), however, show high adaptability on tin-mined lands (Latifah, 2000; Setiawan, 2003). A. mangium was reported successfully as a nurse tree on degraded sandy soil (Norisada et al., 2005). Local species, i.e. Hibiscus tiliaceus L. (Malvaceae), Ficus superba Miq. (Moraceae), Calophyllum inophyllum L. (Clusiaceae) and Syzygium grande (Wight) Wight Walp. (Myrtaceae) were reported adaptive on tin-mined lands (Nurtjahya et al., 2008c). Some morphological and physiological characteristics of some local tree species planted in previously tin-mined lands, such as stomata density, leaf tissue ratio, and root conductivity showed their adaptability on tin-mined lands (Nurtjahya and Juairiah, 2006). 
Planting annual plants on previously tin-mined lands by some farmers is another example of paying attention to species adaptability on land which is exposed to water stress; low water holding capacity. Rice, a member of Poaceae, has a lifespan of 90-120 d in the field, and may show good adaptability to the previously tinmined rice field environment.

\subsection{Feasibility}

From the heavy metal content perspective, rice grain can be considered safe and relatively similar to rice control samples. The heavy metals contents were not significantly different from mined and unmined husk. This finding also in line with two reports that earlier indicated that there were no chemical toxicities to plants (Kusumastuti, 2005; PPTA, 1996). Some above normal heavy metal concentrations of a few demersal fish in 'kolong' were reported (PT Timah Tbk. - Lembaga Penelitian Universitas Sriwijaya, 2000).

The production of IR64 dried unhulled rice and rice grains in Jeruk village was a considerable harvest compared with the same short day rice variety group planted in unmined soil in other parts of Indonesia. The yield of 4-5 t/ha dried unhulled IR64 rice from previously tin-mined land was still below the reported harvest of 5.5-6.5 t/ha in Java (Kompas, 2009a), and the IP400 rice variety which may produce 7.1 t/ha dried unhulled rice with four crops a year harvest (Kompas, 2009b), or with a new local variety produced by local farmers in Central Java 8-9 t/ha (Kompas, 2009a).

If the land preparation for rice field construction, mineral soil and compost costs are excluded, the pilot project in previously tin-mined land for planting rice benefit is about 9-12 million $\mathrm{Rp} / \mathrm{ha}$; when included, losses of 10-13.8 million $\mathrm{Rp} / \mathrm{ha}$ are incurred. The benefits come from the harvest which cannot support soil amendment following land degradation caused by tin mining. Other studies valuing land use which is changed such as pepper and rubber plantation into mined areas (Nurtjahya et al., 2007a), and the land use of coastal area to mined area (Nurtjahya et al., 2008b) conclude that, in general, the benefits generated from tin mining cannot cover the reclamation and revegetation of previously tin-mined lands. The economic benefit is not balanced with the environmental loss. The net income of fishermen is 2.9 million Rp/person/month over a long time period and the net income of miners in Rebo Beach and Bubus Beachwere 5.4-6 million Rp/person/month for about 6 months. Coral reef rehabilitation takes at least 70 million $\mathrm{Rp} / \mathrm{ha}$ and requires 20-30 years to recover (Nurtjahya et al., 2008b).

Considerable effort may be made to modify soil amendment procedures in order to increase the benefit which may cover environmental loss. The research would study the different levels of mineral soil and compost and seeking the most economical treatment. The use of fish net is a good alternative to prevent bird attack.

\section{Conclusions}

Changing previously tin-mined land into rice field is a good practice to support food supply in the province of Bangka Belitung Islands since most of major staples come from other islands. This is a pioneer project of Bangka Goes Green, a corporate social responsibility programme from a private tin smelter consortium in Pangkalpinang, Bangka Island. The work, which has not been practiced before in the province, has demonstrated to some key local and provincial government officers the importance of integrated agriculture in order to solve problems of land use in mined areas. Apart from the agricultural success, considerable effort should now be made so as to be able to repay the environmental loss and achieve real benefits from the rice fields. As they are major costs, soil amendment or land preparation procedures need to have some modifications.

\section{Acknowledgements}

The first author gratefully acknowledges the funding of this research by Proyek Kerjasama Universitas Bangka Belitung dan Bangka Goes Green. The authors also thank the management of Bangka Goes Green for permission to access the rice field area for research purposes and collection of secondary data. The authors would like to thank the dean of Faculty of Agriculture, Fishery and Biology and the joint research team of Universitas Bangka Belitung and Bangka Goes Green for their support. Special thanks to the reviewers for their valuable comments on the manuscript. 


\section{References}

Ang, L.H. (1994) Problems and prospects of afforestation on sand tin tailings in peninsular Malaysia, Journal of Tropical Forest Science, Vol. 7, pp. 87-105.

Ang, L.H. and Ang, T.B. (2000) Greening the tin tailing areas in Malaysia, In Proceedings Conference on Forestry and Forest Products Research, S. Appanah, M.Y. Yusmah, W.J. Astinah and K.C. Khoo (eds), 2-4 November 1997, Kepong, Malaysia, FRIM, pp. 195-205.

Asikin, S. and Thamrin, M. (2009) Pengendalian hama walang sangit (Leptocorisa oratorius F.) di Tingkat Petani Lebak Kalimantan Selatan, viewed 16 May 2009, http://balittra.litbang.deptan.go.id/abstract/Document8.pdf.

Asosiasi Tambang Timah Rakyat (ASTIRA) (2005) Tambang Rakyat Potensi Terabaikan, Asosiasi Tambang Timah Rakyat, Pangkalpinang, artikel (unpublished).

Kompas (2009a) Pemerintah belum serius kembangkan benih padi lokal, Kompas, Jakarta 18 April 2009.

Kompas (2009b) Panen padi empat kali dalam setahun, Kompas, Jakarta, 25 April 2009.

Kusumastuti, E. (2005) Rehabilitasi Lahan Pasca Penambangan Timah di Pulau Bangka dengan Amelioran Bahan Organik dan Bahan Tanah Mineral dengan Tanaman Indikator Jati (Tectona grandis), Sekolah Pascasarjana Institut Pertanian Bogor, Bogor, M.Sc. thesis (unpublished).

Latifah, S. (2000) Keragaan pertumbuhan Acacia mangium Willd. pada lahan bekas tambang timah (studi kasus di areal kerja PT Timah Tbk., Sekolah Pascasarjana Institut Pertanian Bogor, Bogor, M.Sc. thesis (unpublished).

Metro Bangka Belitung (2008) Edisi Khusus Bangka Goes Green, Bangka Goes Green, Pangkalpinang, Edisi Khusus.

Mitchell, B.A. (1959) The ecology of tin mine spoil heaps, Part I sand and gravel tailings, Malayan Forestry 22, pp. 111-132.

Naning, M.I., Diha, M.A. and Gofar, N. (1999) Perbaikan sifat kimia bahan tailing asal lahan pasca penambangan timah dan pertumbuhan tanaman jagung dengan pemberian bahan organik dan zeolit, In Prosiding Seminar Hasil Penelitian Universitas Sriwijaya, Palembang, Maret 1999, 16 p.

Norisada, M., Hitsuma, G., Kuroda, K., Yamanoshita, T., Masumori, M., Tange, T., Yagi, H., Nuyim, T., Sasaki, S. and Kojima, K. (2005) Acacia mangium, a nurse tree candidate for reforestation on degraded sandy soils in the Malay Peninsula, Forest Science, Vol. 51, pp. 498-510.

Nurtjahya, E. (2008) Revegetasi Lahan Pasca Tambang Timah dengan Beragam Jenis Pohon Lokal di Pulau Bangka, Sekolah Pascasarjana Institut Pertanian Bogor, Bogor. PhD thesis (unpublished).

Nurtjahya, E., Setiadi, D., Guhardja, E., Muhadiono, Setiadi, Y. (2008a) Revegetation of tin-mined land using various local tree species in Bangka Island, Indonesia, Di dalam: Barnhisel RI, (ed) 2008, 2008 National Meeting of the American Society of Mining and Reclamation, Richmond VA, New Opportunities to Apply Our Science on June 14-19, 2008, Lexington: ASMR, pp. 739-755.

Nurtjahya, E., Agustina, F. and Akbar, A. (2008b) Kajian Manfaat Sosial Ekonomi Penambangan Timah Inkonvensional Dan Kerusakan Lingkungan Dan Keanekaragaman Hayati Yang Ditimbulkannya Di Pulau Bangka - Studi Kasus Penambangan Perairan Pantai. Lap. Tahun II/Akhir Hibah Bersaing XV (086/SP2H/PP/ DP2M/III/2008).

Nurtjahya, E., Setiadi, D., Guhardja, E., Muhadiono and Setiadi, Y. (2008c) Establishment of four local tree species for potential revegetating of tin-mined land in Bangka Island, Indonesia, In Proceedings of the Third International Seminar on Mine Closure, Mine Closure 2008, A.B. Fourie, M. Tibbett, I.M. Weiersbye, P. Dye (eds), 14-17 October 2008, Johannesburg, South Africa, Australian Centre for Geomechanics, Perth, pp. 751-758.

Nurtjahya, E., Agustina, F. and Putri, W.A.E. (2007a) Kajian Manfaat Sosial Ekonomi Penambangan Timah Inkonvensional Dan Kerusakan Lingkungan Dan Keanekaragaman Hayati Yang Ditimbulkannya Di Pulau Bangka - Studi Kasus Penambangan Darat. Lap. Tahun I Hibah Bersaing XV (092/SP2H/PP/DP2M/III/2007).

Nurtjahya, E., Setiadi, D., Guhardja, E., Muhadiono and Setiadi, Y. (2007b) Succession on tin-mined land in Bangka Island in The Seventh International Flora Malesiana Symposium, 17-22 June 2007, Leiden, The Netherlands, $7 \mathrm{p}$.

Nurtjahya, E. and Juairiah, L. (2006) Struktur anatomi dan karakter fisiologi tanaman pionir di lahan pasca penambangan timah di Riding Panjang, Bangka, Universitas Bangka Belitung, Sungailiat, 31 p.

Nurtjahya, E. (2001) Revegetation on tin post mining area in Bangka Island (bibliographical review), Indonesian Mining Journal, Vol. 7, pp. 32-37.

Pangkalpinang Meteorology Station (2006) Data iklim Bangka 1996-2005, Stasiun Meteorologi Pangkalpinang, Pangkalpinang (unpublished).

PT Timah Tbk. - Lembaga Penelitian Universitas Sriwijaya (2000) Identifikasi Kolong Pasca Penambangan Timah di Wilayah Bangka-Belitung, PT Timah Tbk., Pangkalpinang, Laporan Akhir (unpublished).

Puryanto, E. (1983) Rehabilitasi tanah pasir kuarsa eks tambang timah pulau Bangka dengan bahan-bahan alamiah untuk budidaya tanaman jambu monyet (Anacardium occidentale L.), Institut Pertanian Bogor, Bogor, B.Sc. thesis (unpublished).

Pusat Penelitian Tanah dan Agroklimat (PPTA) (1996) Laporan akhir penelitian studi upaya rehabilitasi lingkungan penambangan timah, Pusat Penelitian Tanah dan Agroklimat, Bogor, Laporan Akhir (unpublished). 
Rogan, N., Serafimovski, T., Dolonec, M., Tasev, G. and Dolonec, T. (2009) Heavy metals contamination of paddy soils and rice (Oryza sativa L.) from Kočani Field (Macedonia), Environmetal Geochemistry and Health, Vol. 31, pp. 439-451.

Sastrodihardjo, S. (1990) Pengaruh pemberian bahan organik dan polimer alam serta sintetik terhadap beberapa sifat fisik dan kimia tanah tailing tambang 25 wilasi Pangkalpinang Unit Penambangan Timah Bangka (UPTB), Institut Pertanian Bogor, Bogor, B.Sc. thesis (unpublished).

Setiawan, I.E. (2003) Evaluasi tingkat keberhasilan revegetasi pada lahan bekas tambang timah PT Koba Tin, Koba, Bangka Belitung, Institut Pertanian Bogor, Bogor, B.Sc. thesis (unpublished).

Setyorini, D., Adiningsih, J.S. and Rochayati, S. (2003) Uji Tanah Sebagai Dasar Penyusunan Rekomendasi Pemupukan, Balai Penelitian Tanah, Pusat Penelitian dan Pengembangan Tanah dan Agroklimat, Bogor, 136 p.

Siagian, Y.T. and Harahap, R.M.S. (1981) Hasil pendahuluan percobaan pemilihan jenis-jenis pohon pada lahan kolong pasir kuarsa di Dabo, Singkep, Balai Penelitian Hutan, Bogor, Laporan Balai Penelitian Hutan No. 384, (unpublished).

Soerianegara, I. and Indrawan, A. (2002) Ekologi Hutan Indonesia, Laboratorium Ekologi Hutan, Fakultas Kehutanan, Institut Pertanian Bogor, Bogor, 167 p. 